\title{
Assessment of Genetic Diversity in Mid-late Maturing Sugarcane Clones under Waterlogging Condition in Lower Indo-gangetic Plains
}

\author{
Divya Prakash ${ }^{1 *}$, D. N. Kamat ${ }^{2}$ and Bal Krishna ${ }^{3}$ \\ ${ }^{1}$ Department of Genetics and Plant Breeding, I.A.S, B.H.U, Varanasi, U.P, India \\ ${ }^{2}$ Sugarcane Research Institute, Dr Rajendra Prasad Central Agricultural University, \\ Pusa (Samastipur)-848125, India \\ ${ }^{3}$ Department of Plant Breedingand Genetics, B.A.U Sabour, Bihar, India \\ *Corresponding author
}

\section{A B S T R A C T}

\section{Keywords}

Floods in Bihar, ANOVA, correlation and path

Article Info

Accepted:

17 June 2020

Available Online:

10 July 2020
The lower Indo-gangetic plains of India comprising of eastern Uttar Pradesh, Bihar and West Bengal are frequently flooded by tributaries of Ganga during monsoon and there is a need to provide waterlog stress resilient sugarcane clones to farmers for cultivation. Assessment of genetic diversity is important in any breeding endeavour to achieve success. Sixteen sugarcane clones of mid-late maturity groups were evaluated for twenty three different morphological and physiological characters in the year 2017-18. The experiment was carried out at Paddy Block of Research Farm, R.P.C.A.U.,Pusa, Samastipur, Bihar which is situated alongside the bank of river BurhiGandak, a tributary of river Ganga. The field remained waterlogged during monsoon with maximum depth of water being $140 \mathrm{~cm}$. Mahalnobis $\mathrm{D}^{2}$ distances were computed and clusters were formed using tochers method which grouped genotypes in 6 clusters with cluster 5 and 6 having single genotypes. The lowest intra-cluster distance value of zero was observed for cluster 5 and 6 as they contained dingle genotype and highest value of intra-cluster distance was observed for cluster 2. The largest inter-cluster distance was observed between cluster 2 and 5 and lowest between cluster 1 and 3. Characters such as chlorophyll b content, chlorophyll a content and total chlorophyll content showed largest contribution towards divergence. Cluster 5 containing a single genotype CoP2061 had highest mean value for cane and sugar yield followed by cluster 1 and 3 . Thus, genotypes in these clusters can be used in further breeding programmes. Similarly other genotypes in other clusters may well be used for targeting a particular trait in a particular environment in ideotype breeding programmes.

\section{Introduction}

Sugarcane is the world's leading crop in terms of harvested tonnage and a widely grown crop in tropical and subtropical areas of the world. Sugarcane provides sugar and many more products such as gur, khandsari, molasses, pressmud and Bagasse. Ethanol extracted from molasses can be used as fuel for transport system. Pressmud can be used as bio-compost to enrich soils and bagasse can be used for generation of electricity. India 
produced about 376.9 million tonnes of sugarcane in an area of 4.73 million hectares in the year 2017-18 (Directorate of Economics and Statistics, Government of India). The sugarcane production in Bihar was around 165.11 lakh tonnes with the productivity around 67.9 tonnes per hectare in 2017.

A large part of India consisting of Assam, Bihar, West Bengal, Eastern U.P, coastal regions of Andhra Pradesh, Tamil Nadu, Kerala and Karnataka are exposed to stagnant water for two or more months during rainy season. India is one of the centres of origin of sugarcane and thus, gene pool from this region may have vital genes for waterlogging tolerance. Genomics has made rapid advances and sequencing of sugarcane genome would identify alleles in this crop that may be beneficial in crop improvement. Identification of genes and alleles conferring waterlogging stress tolerance would require identification of genotypes that perform better under waterlog stress conditions and its consequential use in creation of mapping populations or genome sequencing. Zhang et al., (2018) has reported sequencing of haploid Saccharum spontaneum line AP85-441.

Sugarcane is a major crop in North West Alluvial agro-climatic zone of Bihar and all the districts except Vaishali and Begusarai in this zone, were affected by floods in the year 2017.The estimated crop damage in monetary value was pegged at $\square 6858.7$ million (95.96 million USD) due to flood affected cropped area of 87.3 million hectare in flood report 2017 of Bihar. "The rivers namely Ghaghra, Gandak, BurhiGandak, Bagmati, Kamla, Adhwara group of rivers, Kosi and Mahanada have Himalayan origin and have considerable portion of their catchment in the galcial region falling in Nepal and Tibet, and are therefore positioned to receive very copious rainfall during monsoon when discharge of these rivers is 50 to 90 times larger than fair weather flow. This causes frequent and large scale flooding of North Bihar. As such, 73.63 percent of the geographical area of North Bihar is considered to be prone to floods (The State Disaster Management Plan, Perspective)". The districts in North Bihar, the major sugarcane producing area of the state, are regularly affected by floods.

A successful breeding programme needs to identify genotypes that may be used in breeding programmes and classificatory analysis such as $\mathrm{D}^{2}$ statistics clusters genotypes and enables to group similar genotypes so as to understand the extent of similarity or dissimilarity to make informed decision on the crosses to be made for achieving a particular objective in plant breeding, in this case breeding tolerance to waterlogging conditions. Diversity analysis has been commonly used by breeders across species under different environments however few studies have been done prior to this study in lower gangetic plains though the area is greatly affected by floods on an yearly basis. Furthermore, the study becomes significant as the crop was under severe waterlogging stress as a result of severe flooding in the year 2017.

\section{Materials and Methods}

\section{Experimental layout and materials}

The experiment was laid out in Randomized complete block design with three replications. The description of genotypes is given in table 1. The recommended package of practices for agro-climatic region of Bihar, were followed.

\section{Experimental site topography and climate}

The experiment was conducted at Paddy Block of Research Farm of R.P.C.A.U. Pusa, Samastipur, Bihar situated between $25.97^{0} \mathrm{~N}$ latitude and $85.66^{\circ} \mathrm{E}$ longitudes at $51.8 \mathrm{~m}$ 
above mean sea level. The plot which was well levelled remained waterlogged during monsoon as it was a lowland area alongside the river BurhiGandak. The maximum depth of water was about $140 \mathrm{~cm}$ for 30 days in August-September.

\section{Observations recorded}

Twenty three different morphological, biochemical and juice quality parameters viz. germination percentage at $45 \mathrm{DAP}$, number of shoots at 120 DAP, plant height at harvest $(\mathrm{cm})$, leaf area per plant before and after waterlogging, number of nodes with aerial roots, cane diameter at harvest $(\mathrm{cm})$, number of shoots at 240 DAP (000/ha), number of millable canes at harvest (000/ha), single cane weight $(\mathrm{kg})$, Brix, Pol and Purity at $10 \& 12$ months stage (\%), cane yield ( $\mathrm{t} / \mathrm{ha}), \mathrm{CCS} \%$ at 10 and 12 months stage, sugar yield (CCS $\mathrm{t} / \mathrm{ha}$ ) at harvest, chlorophyll "a" content, chlorophyll "b" content and total chlorophyll content were studied and observations were recorded. Leaf area per plant was obtained as the product of breadth at the broadest part of leaf and length of the leaf with the factor 0.6274 (Bathla and Sharma, 1978). The leaf area per plant was obtained by summation of leaf area of all the leaves.

A sample consisting of five randomly selected cane stalks were crushed in a cane crusher and the juice obtained was poured in graduated measuring cylinders of $500 \mathrm{ml}$ and brix hydrometer was suspended in this cylinder. The Brix reading was recorded when the brix hydrometer stopped oscillating in the cylinder. To obtain Pol reading, $100 \mathrm{ml}$ juice of each sample was taken in a beaker and about $1-1.5 \mathrm{~g}$ of basic anhydrous lead acetate was added to it. The mixture was then stirred and kept for some time so as to precipitate non soluble substance. The precipitated impurities were filtered off and clear filtrate juice was collected. The clear filtered juice was filled in $20 \mathrm{~cm}$ long polarimeter tube.
This tube was placed in the body of polarimeter and pol reading was recorded. Schmitz table (Spencer and Meade, 1955), was used to note the sucrose percent in juice using corresponding values of the brix and Pol reading.

The percentage of sugar in total solid is called purity percentage. The juice purity percentage was calculated by using the formula; Purity Percent $(\%)=\frac{\text { Pol in juice }}{\text { Juice Brix }} \times 100$. The cane yield was taken at the time of harvesting. Cane yield ( $\mathrm{t} / \mathrm{ha}$ ) was recorded by harvesting and weighing the all canes in a plot and the values then converted into tonnes/ha. CCS $\%$ was estimated from sucrose in juice and brix reading using the formula; CCS percent $=$ $[\mathrm{S}-(\mathrm{B}-\mathrm{S}) \times 0.4] \times 0.73$, where $\mathrm{S}$ is Sucrose percent in juice (Pol \%) and B isBrix percent in juice. Chlorophyll content measurement was done using DMSO as described by Hiscox and Israelstam, 1979. Three to five plants were sampled for observations.

\section{Statistical Analysis}

The divergence among sugarcane clones was estimated through the use of Mahalanobis Generalized Distance (Mahalnobis, 1928) as a measure of genetic dissimilarity and the genotypes were clustered using Tocher method as suggested by Rao (1952). The contribution of characters towards divergence was computed as given by Singh and Choudhary.

\section{Results and Discussion}

The clustering of genotypes following tochers method grouped the genotypes in 6 clusters as shown in table 1. Genotypes CoP 09437, CoP 15439, CoP15440, B.O 156 and B.O 91 were present in cluster 1 , clones CoP 12438, CoP 12439, CoP 11439 andCoP 14439 formed cluster 2, clones B.O 155, CoP 14438 and CoP 16439 became part of cluster 3, clones 
B.O 154 and CoP16440 formed cluster 4. Cluster 5 and 6 contained one genotype each i.e CoP2061 and CoP15441 respectively.

Inter and Intra cluster distances has been shown in table 3. Intra-cluster distances present on diagonal of table depicts lowest intra-cluster distance value of zero for cluster 5 and 6 while highest value of intra-cluster distance was observed for cluster 2 . The largest inter-cluster distance was observed between cluster 2 and 5 and lowest between cluster 1 and 3. All inter cluster distance was found to be between these two extremes.

Cluster means for all the characters studied along with population mean for the charcter has been presented in table 4. The abbreviation used for the characters studied has been presented in column 3 of table 4 . Cluster 1 had larger mean value than population mean for NAR, S240, NMC, B10M, P10M, PU10M, CCS10, B12M, P12M, PU12M, CCS12M, CY and SY, whereas cluster 2 had lower mean values for most of the studied characters except G\%, S120, S240, SCW, B12M and PH. Cluster 3 had higher mean than population mean for most of the characters studied except $\mathrm{G} \%$, NMC, B10M, P10M, B10M, P10M and PU10M. The genotypes in cluster 4 had higher average mean than population mean for G\%, LAPPAW, NAR, CD, S240, SCW, PU12M, CHLa, CHLb and TCHL.. Cluster 5 containing a single genotype CoP2061 had higher mean values for almost all the characters except LAPPBW, NAR, PU12M and $\mathrm{CHLb}$ whereas cluster 6 having a single genotype had lower mean values for $G \%$, S120, LAPPBW, LAPPAW, CD, S240, NMC, SCW, CCS12M, CY, SY, CHLb and $\mathrm{PH}$ than population mean among the characters studied. Cluster 5, 1 and 3 had higher higher mean value than population mean for cane yield and sugar yield in descending order.
The contribution of individual characters towards divergence is shown in table 5. It can be seen that chlorophyll b content, chlorophyll a content and total chlorophyll content had largest contribution towards divergence. Cane yield followed by purity at 12 months had small contribution towards divergence. Number of shoots at 240 DAP and number of millable canes (000/ha) had negligible contribution towards divergence.

The clustering of the studied genotypes based on Mahalnobis $\mathrm{D}^{2}$ distances showed that genotypes can be grouped into 6 clusters as shown in table 2 . Cluster 1 contains 5 genotypes followed by cluster 2, 3 and 4 with 4, 3 and 2 genotypes respectively.

Clusters 5 and 6 contains one genotype each suggesting that these genotypes were too different from other genotypes with respect to the characters studied to be clustered within any of them. Clone BO91 has been an elite sugarcane variety that has been used in breeding programmes world over. BO91 along with its half sib CoP09437 finds place in cluster 1 whereas CoP12438 and CoP 14438 are present in clusters 2 and 3 respectively.

The largest intra cluster distance was observed for cluster 2 suggesting that genotypes within this group had more variability compared to genotypes within other groups. The value zero is seen for intracluster distance of cluster 5 and 6 as these clusters contained a single genotype. The largest inter-cluster distance was observed between cluster 2 and 5 and lowest between cluster 1 and 3 suggesting that these clusters were highly divergent and most similar with respect to the studied characters respectively.

Cane yield and sugar yield are the most important characters from breeder's perspective as farmers and industry want 
increased productivity. It can be seen that cluster 5 containing single genotype CoP2061 had highest values for cane and sugar yield followed by cluster 1 and 3 . Thus genotypes in these clusters can be used in further breeding programmes. The standard practice in breeding to obtain high amount of variability in segregating generations is to cross most divergent plants and screen the segregating populations to obtain transgressive segregants. Thus it would be advisable to cross genotypes in cluster 2 with CoP2061 forming cluster 5 to obtain large variability for yield in segregating populations and screen for transgressive segregants for yield under waterlogged condition. Sugarcane is a highly heterozygous crop and genotypes being vegetatively propagated contains large reserves of potential variability. Thus, even selfing of clones can result in enough variability to breed new varieties. Genotypes of cluster 5, 2 and 3 can be intermated to breed for high yield under waterlogging condition as they probably contain high yield QTLs as shown by their high mean values for cane and sugar yield.

Table.1 Clones used in the study, their parentage and source

\begin{tabular}{|c|l|l|l|}
\hline Sl. No. & \multicolumn{1}{|c|}{ Clones } & \multicolumn{1}{|c|}{ Parent } & \multicolumn{1}{|c|}{ Source } \\
\hline $\mathbf{1 .}$ & BO 154 & CoSe98235 X UP 9742 & S.R.I. Pusa \\
\hline $\mathbf{2 .}$ & BO 155 & BO $122 \mathrm{FC}$ & S.R.I. Pusa \\
\hline $\mathbf{3 .}$ & BO 156 & BO 150 (self) & S.R.I. Pusa \\
\hline $\mathbf{4 .}$ & BO 91 & BO 55 X BO 43 & S.R.I. Pusa \\
\hline $\mathbf{5 .}$ & CoP 09437 & BO 91 GC & S.R.I. Pusa \\
\hline $\mathbf{6 .}$ & CoP 11439 & CO 88039 GC & S.R.I. Pusa \\
\hline $\mathbf{7 .}$ & CoP 12438 & BO 91 X CO 1158 & S.R.I. Pusa \\
\hline $\mathbf{8 .}$ & CoP 12439 & BO 97 XCoH 15 & S.R.I. Pusa \\
\hline $\mathbf{9 .}$ & CoP 14438 & BO 91 GC & S.R.I. Pusa \\
\hline $\mathbf{1 0 .}$ & CoP 14439 & Co Pant 90223 GC & S.R.I. Pusa \\
\hline $\mathbf{1 1 .}$ & CoP 15439 & CoSe 01268 GC & S.R.I. Pusa \\
\hline $\mathbf{1 2 .}$ & CoP 15440 & CoSe 01268 GC & S.R.I. Pusa \\
\hline $\mathbf{1 3 .}$ & CoP 15441 & CO 88216 GC & S.R.I. Pusa \\
\hline $\mathbf{1 4 .}$ & CoP 16439 & CoSe 92423 X CoS 8436 & S.R.I. Pusa \\
\hline $\mathbf{1 5 .}$ & CoP 16440 & CoS 86216 & S.R.I. Pusa \\
\hline $\mathbf{1 6 .}$ & CoP 2061 & CoLk 8102 X HR $83 / 65$ & S.R.I. Pusa \\
\hline
\end{tabular}

Table.2 Inter and Intra-cluster distances

\begin{tabular}{|r|r|r|r|r|r|r|}
\hline Cluster & $\mathbf{1}$ & $\mathbf{2}$ & $\mathbf{3}$ & $\mathbf{4}$ & $\mathbf{5}$ & $\mathbf{6}$ \\
\hline $\mathbf{1}$ & 1209.178 & & & & & \\
\hline $\mathbf{2}$ & 19456.74 & 2885.932 & & & & \\
\hline $\mathbf{3}$ & 6150.289 & 6792.781 & 752.8985 & & & \\
\hline $\mathbf{4}$ & 37452.73 & 106242.5 & 69855.26 & 1366.228 & & \\
\hline $\mathbf{5}$ & 63967.15 & 149615.5 & 105528.4 & 5661.313 & 0 & \\
\hline $\mathbf{6}$ & 6792.781 & 46130.92 & 23354.06 & 13560.34 & 30781.73 & 0 \\
\hline
\end{tabular}


Table.3 Cluster and population means for different characters

\begin{tabular}{|c|c|c|c|c|c|c|c|c|c|}
\hline S.No & Characters & $\begin{array}{l}\text { Abbreviatio } \\
\text { n used }\end{array}$ & $\begin{array}{c}\text { Cluster } \\
1\end{array}$ & $\begin{array}{l}\text { Cluster } \\
2\end{array}$ & $\begin{array}{c}\text { Cluster } \\
3\end{array}$ & $\begin{array}{c}\text { Cluster } \\
4\end{array}$ & $\begin{array}{c}\text { Cluster } \\
5\end{array}$ & $\begin{array}{l}\text { Cluster } \\
6\end{array}$ & $\begin{array}{l}\text { Population } \\
\text { Mean }\end{array}$ \\
\hline 1 & $\begin{array}{l}\text { Germination } \\
\text { percentage at } 45 \text { DAS }\end{array}$ & $\mathrm{G} \%$ & 41.38 & 44.92 & 41.93 & 43.44 & 46.00 & 35.11 & 42.52 \\
\hline 2 & $\begin{array}{l}\text { Number of shoots at } \\
120 \text { DAP }(000 / h a)\end{array}$ & S120 & 60.15 & 74.42 & 64.10 & 54.86 & 76.54 & 24.85 & 62.62 \\
\hline 3 & $\begin{array}{l}\text { Leaf area per plant } \\
\text { before waterlogging } \\
\left(\mathrm{cm}^{2}\right)\end{array}$ & LAPPBW & 1460.73 & 1603.18 & 2175.58 & 1970.49 & 1384.60 & 1029.29 & 1662.37 \\
\hline 4 & $\begin{array}{l}\text { Leaf area per plant } \\
\text { after waterlogging } \\
\left(\mathrm{cm}^{2}\right)\end{array}$ & LAPPAW & 1715.19 & 1711.17 & 2160.87 & 1947.27 & 2190.08 & 1249.36 & 1827.33 \\
\hline 5 & $\begin{array}{l}\text { Number of nodes with } \\
\text { aerial roots }\end{array}$ & NAR & 7.30 & 6.73 & 7.39 & 7.25 & 5.75 & 7.83 & 7.10 \\
\hline 6 & $\begin{array}{l}\text { Cane diameter at } \\
\text { harvest }(\mathrm{cm})\end{array}$ & $\mathrm{CD}$ & 2.25 & 2.20 & 2.40 & 2.44 & 2.48 & 2.30 & 2.31 \\
\hline 7 & $\begin{array}{l}\text { Number of shoots at } \\
240 \text { DAP(000/ha) }\end{array}$ & S240 & 101.21 & 100.85 & 101.66 & 95.75 & 112.62 & 69.20 & 99.24 \\
\hline 8 & $\begin{array}{l}\text { Number of millable } \\
\text { canes (000/ha) }\end{array}$ & NMC & 88.66 & 83.32 & 83.32 & 75.11 & 100.83 & 63.42 & 83.81 \\
\hline 9 & $\begin{array}{l}\text { Single cane weight } \\
(\mathrm{Kg})\end{array}$ & SCW & 0.683 & 0.670 & 0.702 & 0.727 & 0.843 & 0.680 & 0.699 \\
\hline 10 & Brix at 10 months & B10M & 17.3 & 17.2 & 17.1 & 17.1 & 17.9 & 17.9 & 17.3 \\
\hline 11 & Pol at 10 months & P10M & 15.02 & 14.78 & 14.83 & 14.83 & 15.54 & 15.56 & 14.97 \\
\hline 12 & Purity at 10 months & PU10M & 87.1 & 86.0 & 86.8 & 86.6 & 87.0 & 87.1 & 86.7 \\
\hline 13 & CCS\% at 10 months & CCS10 & 10.30 & 10.09 & 10.17 & 10.16 & 10.66 & 10.68 & 10.25 \\
\hline 14 & Brix at 12 months & B12M & 19.0 & 18.8 & 19.0 & 18.7 & 19.9 & 19.7 & 19.0 \\
\hline 15 & Pol at 12 months & P12M & 16.76 & 16.42 & 16.77 & 16.45 & 17.41 & 17.58 & 16.73 \\
\hline 16 & Purity at 12 months & PU12M & 88.3 & 87.6 & 88.4 & 88.1 & 87.7 & 89.2 & 88.1 \\
\hline 17 & $\mathrm{CCS} \%$ at 12 months & CCS12M & 11.58 & 11.30 & 11.60 & 11.36 & 12.00 & 12.21 & 11.55 \\
\hline 18 & Cane yield(tonnes/ha) & CY & 59.66 & 54.69 & 59.61 & 55.73 & 84.96 & 43.12 & 58.46 \\
\hline 19 & $\begin{array}{l}\text { Sugar yield at harvest } \\
\text { (tonnes/ha) }\end{array}$ & SY & 6.91 & 6.19 & 6.84 & 6.46 & 10.19 & 5.27 & 6.76 \\
\hline 20 & $\begin{array}{l}\text { Chlorophyll a (mg per } \\
\text { gram fresh weight) }\end{array}$ & CHLa & 0.739 & 0.591 & 0.530 & 1.150 & 1.119 & 0.878 & 0.747 \\
\hline 21 & $\begin{array}{l}\text { Chlorophyll b (mg per } \\
\text { gram fresh weight) }\end{array}$ & CHLb & 0.114 & 0.109 & 0.153 & 0.269 & 0.119 & 0.107 & 0.139 \\
\hline 22 & $\begin{array}{l}\text { Total chlorophyll (mg } \\
\text { per gram fresh weight) }\end{array}$ & TCHL & 0.853 & 0.699 & 0.683 & 1.419 & 1.238 & 0.958 & 0.886 \\
\hline 23 & $\begin{array}{l}\text { Plant height at } \\
\text { harvest(in } \mathrm{cm} \text { ) }\end{array}$ & $\mathrm{PH}$ & 228.33 & 242.15 & 231.19 & 217.58 & 250.58 & 188.50 & 229.88 \\
\hline
\end{tabular}


Table.4 Contribution of characters towards divergence

\begin{tabular}{|c|c|c|}
\hline Characters & $\begin{array}{c}\text { Times } \\
\text { ranked } \\
\text { first }\end{array}$ & $\begin{array}{c}\text { Contribution in } \\
\text { percentage }\end{array}$ \\
\hline Germination percentage at 45 DAS & 0 & 0 \\
\hline Number of shoots at 120 DAP $(000 / h a)$ & 0 & 0 \\
\hline Leaf area per plant before waterlogging $\left(\mathrm{cm}^{2}\right)$ & 0 & 0 \\
\hline Leaf area per plant after waterlogging $\left(\mathrm{cm}^{2}\right)$ & 0 & 0 \\
\hline Number of nodes with aerial roots & 0 & 0 \\
\hline Cane diameter at harvest(cm) & 0 & 0 \\
\hline Number of shoots at $240 \mathrm{DAP}(000 / \mathrm{ha})$ & 0 & 0 \\
\hline Number of millable canes $(000 / h a)$ & 1 & 0.8333 \\
\hline Single cane weight $(\mathrm{Kg})$ & 1 & 0.8333 \\
\hline Brix at 10 months & 0 & 0 \\
\hline Pol at 10 months & 0 & 0 \\
\hline Purity at 10 months & 0 & 0 \\
\hline CCS\% at 10 months & 0 & 0 \\
\hline Brix at 12 months & 0 & 0 \\
\hline Pol at 12 months & 0 & 0 \\
\hline Purity at 12 months & 2 & 1.6667 \\
\hline CCS\% at 12 months & 0 & 0 \\
\hline Cane yield(tonnes/ha) & 5 & 4.1667 \\
\hline Sugar yield at harvest (tonnes/ha) & 0 & 0 \\
\hline Chlorophyll a (mg per gram fresh weight) & 26 & 21.6667 \\
\hline Chlorophyll b (mg per gram fresh weight) & 73 & 60.8333 \\
\hline Total chlorophyll (mg per gram fresh weight) & 12 & 10 \\
\hline Plant height at harvest(in cm) & 0 & 0 \\
\hline
\end{tabular}

Ideotype breeding aims to develop genotypes for particular environment by targeting phenology of a crop and modifying it in a certain way. The study shows that genotypes in cluster 5 and cluster 4 have higher chlorophyll content even under waterlogged condition and thus breeding programmes targeting this trait may well utilise these genotypes. Similarly other genotypes can well be used for targeting a particular trait under different environments.

The characters that were the most important contributors towards divergence in the present study were chlorophyll content (chlorophyll a and $b$, total chlorophyll). The character cane yield followed by purity at 12 months had small contribution towards divergence whereas number of shoots at 240 DAP and number of millable canes at harvest (000/ha) had negligible contribution towards divergence. Single cane weight, cane yield and quality attributes like Brix percent and purity percent were observed to be contributors towards divergence by Punia et al.(1983) while cane yield and purity percent were observed to be primary contributors towards divergence by Srivastava et al., (1999)and Sanghera et al., (2015) The genotypes were not grown under waterlogged condition by these workers. Bal Krishna et al., reported CCS\% at 12 months, Leaf area 
Index 60 days after waterlogging, Leaf area Index 30 days after waterlogging and plant height at 150 days after planting to be contributors towards divergence in descending order under waterlogged condition however, they had not measured the chlorophyll content in studied genotypes. Chlorophyll content is a biochemical attribute which has been observed to be the most important character towards divergence under waterlogged condition in the present study however it has not been reported by earlier workers as most of the earlier workers did not use it as a character under study.

\section{References}

Krishna, B., Kamat, D.N., Kumari, J. and Prakash, D., 2018. Genetic divergence of sugarcane under waterlogging conditions. Int J Pure App Biosci, 6(1), pp. $210-8$.

Bathla, A.V.L., and Sharma H.L. 1978. Measurement of leaf area in sugarcane (Saccharum officinarum). Indian Sugar Crops Journal 1: 16-17.

Hiscox, J.D., andIsraelstam, G.F. 1979. A method for the extraction of chlorophyll from leaf tissue without maceration. Canadian journal of botany57(12): 1332-1334.
Mahalanobis, P.C., 1928. A statistical study at Chinese head measurement. J. Asiatic Soc. Bengal, 25(3), pp.301-377.

Punia, M.S., Chaudhary, B.S., Hooda,R.S. 1983. Genetic divergence in sugarcane.

Rao, C.R. Advanced statistical methods in biometric research. New York. 1952:351-82.

Sanghera, G.S, Kumar, R., Tyagi, V., Thind, K.S, and Sharma, B. 2015. Genetic divergence among elite sugarcane clones (Saccharum officinarum L.) based on cane yield and quality traits from northern India. J. Exp. Biol. Apr 1;3:184-90.

Singh, R.K., and Chaudhary, B.D. 1979. Biometrical methods in quantitative genetic analysis.Kalyani Publishers, New Delhi, pp 318.

Srivastava, H.M., Srivastava, S., Kumar, R., Misra, G.P.1999 Genetic divergence among interspecific hybrids of sugarcane. Sugar Tech. Jun 1;1(12):19-22.

Zhang, J., Zhang, X,, Tang, H., Zhang, Q., Hua, X., Ma, X.,. .. and Wai, C.M. 2018. Allele-defined genome of the autopolyploid sugarcane Saccharum spontaneum L. Nature genetics 50(11): 1565.

\section{How to cite this article:}

Divya Prakash, D. N. Kamat and Bal Krishna. 2020. Assessment of Genetic Diversity in Midlate Maturing Sugarcane Clones under Waterlogging Condition in Lower Indo-gangetic Plains. Int.J.Curr.Microbiol.App.Sci. 9(07): 1826-1833. doi: https://doi.org/10.20546/ijcmas.2020.907.210 